\title{
Comparative osteology and three dimensional computed tomography of Nile catfishes, in relation to feeding mechanisms
}

\author{
ESHRA, E. A. ${ }^{1 *}$ and EL ASELY, A. M. ${ }^{2}$ \\ ${ }^{1}$ Lecturer of Anatomy and Embryology, Department of Anatomy and Embryology, \\ Faculty of Veterinary Medicine, Benha University, Egypt \\ ${ }^{2}$ Lecturer of Fish Diseases and Management, Department of Fish Diseases and Management, \\ Faculty of Veterinary Medicine, Benha University, Egypt \\ *E-mail: mevet213@gmail.com
}

\begin{abstract}
Introduction: For the first time three- dimensional Computed Tomography was used in a study concerning Nile catfishes heads. Methods: The present study is carried out on 40 heads of four examplar species of catfish families, Bagridae (B. bajad); Clariidae (C.garpineus); Malapteruridae (M. electricus) and Mochokidae (S. schall). Specimens are double-stained for cartilage and bone, as done by Taylor and Van Dyke (1985). Results: the skull of $M$. electricus was consisted of both bones and cartilage, as the frontal, parietal, supraoccipital, postparietal, sphenotic and pterootic were remained cartilages in mature fish. In order to ease the studying process the bones of catfish skulls were arranged in clear twelve series. This arrangement may facilitate the diagnosis of the malformations and other related diseases. Despite the similarity of the feeding apparatus in the Nile-catfish, they have different feeding mechanisms. B. bajad able to feed on large sized preys because of the free branchiostegeal membrane, the large dimensions of the oral and pharyngeal gap limits. M. electricus has another method as we suggest that the liable cartilages which form the skull roof are easily squeezed by voluminous muscles, raise the roof of the mouth and expand the oropharynx. In $S$. schall the narrow oropharyngeal limits and the subterminal mouth are suitable for sucking small mollusks, a process aided by the hard pad of the upper lip and the brush like mandibular teeth. Conclusions: This work provides an anatomical description of the fish heads using 3D CT which may facilitate the diagnosis of malformations and other related diseases. It also discussed the different feeding habits of the Nile Catfish.
\end{abstract}

Keywords: 3D imaging, anatomy, feeding mechanisms, bone series, Nile catfish.

\section{Introduction}

Catfish has a great place in Egypt since the time of ancient Egyptians. Most fishing murals illustrate catfish as, African Catfish, Clarias gariepinus, Schall, Synodontis schall and Bagrus bajad which known in Egypt as Bayad a word meaning white. The Hearst and Ebers papyrus were explained that the ancient Egyptians were used the mashed brain of Malapterurus electricus as a local analgesic and its muscles and skin for rheumatic pain relief as mentioned by Ebbell (1937) and Hrapowet (1960). M.electricus is known in recent time by the name Raad or the Thunderer of the Nile, due to its ability of striking by electricity. Nowadays, literatures dealing with comparative osteology of Nile catfish are little, so this study tries to fill a space in the field of veterinary comparative anatomy. For the first time we used the $3 \mathrm{D}$ computed tomography in imaging the heads of Nile catfish. X ray is hardly applied on fishes especially that of small size, while computed tomography seems to be a promising imaging method (LUE, FANG and MANOLIDIS, 2000). In the field of veterinary medicine, the diagnosis of fish skeleton malformation and other congenital abnormalities is depending on anatomical details of normal fishes, so in this study we will give a detailed osteological structure of cephalic region of Nile catfish, in order to ease diagnosis of malformations.

\section{Materials and Methods}

The present study was carried out on forty heads of apparently healthy cat fish, ten of the following each species: Bagrus bajad, Clarias gariepinus, Synodontis schall and Malapterurus electricus; these specimens were obtained from Alobour fish market during June and July. Different measurements were obtained as in Table $\mathbf{1}, \mathbf{2}$.

Specimens were double-stained for cartilage and bone. For this purpose, they underwent the steps 2 and 4 of protocol of Taylor and Van Dyke (1985) with cartilages stained using their "alternate" Alcian blue 8Gx solution (with 80 parts of $95 \%$ ethanol and 20 parts of glacial acetic acid). Specimens were then transferred to a sodium boratebased neutralization solution, according to the step 5 of Taylor and Van Dyke (1985), for 12 hours. Then the heads bleached by using $15 \%$ hydrogen peroxide, according to step 6 but we used distilled water instead of potassium hydroxide solution. Then the stained heads cleared in $30 \%$ sodium borate solution for three days, the solution replaced every day until the specimens is about 70\% clear (step 7), after that the specimens were transferred to Alizarine red solution $0.1 \%$ in $75 \%$ ethanol to stain bone according to (SPRINGER and JOHNSON, 2000). Potassium hydroxide-based solutions for neutralization and bone stain of Taylor and Van Dyke (1985) were not used because the $\mathrm{KOH}$ seems to macerate 
Table 1. Different measurements of Nile catfishes cranial bones (length \pm SD). Values with different letters ( $a$, b \& c) within the same row differed significantly at least at $\mathrm{P}<0.05$.

\begin{tabular}{|c|c|c|c|c|}
\hline \multirow{2}{*}{$\begin{array}{c}\text { Measurements } \\
\text { Length }(\mathrm{cm})\end{array}$} & \multicolumn{4}{|c|}{ Fish species } \\
\hline & B. Bajad & C .gariepinus & M. electricus & S. Schall \\
\hline Total body length & $26 \pm 1.00^{c}$ & $31.33 \pm 1.53^{\mathrm{b}}$ & $41 \pm 1.00^{\mathrm{a}}$ & $21.33 \pm 1.89 \mathrm{a}$ \\
\hline Head length & $8.50 \pm 0.50^{a}$ & $9.83 \pm 0.76^{\mathrm{a}}$ & $7.5 \pm 0.50^{b}$ & $9.67 \pm 0.76^{\mathrm{a}}$ \\
\hline Os premaxillare & $1.60 \pm 0.10^{b}$ & $1.6 \pm 0.10^{b}$ & $1.9 \pm 0.30^{a}$ & $0.5 \pm 0.10^{c}$ \\
\hline Os maxillare & $1.57 \pm 0.40^{a}$ & $0.50 \pm 0.10^{b}$ & $0.50 \pm 0.10^{\mathrm{b}}$ & $0.50 \pm 0.10^{b}$ \\
\hline Os frontale & $4.50 \pm 0.50^{b}$ & $4.50 \pm 0.50^{b}$ & $4.67 \pm 0.76^{b}$ & $7.73 \pm 0.64^{a}$ \\
\hline Anterior Fontanelle: & $2.27 \pm 0.25^{a}$ & $2.10 \pm 0.26^{\mathrm{a}}$ & $2.30 \pm 0.36^{\mathrm{a}}$ & $1.97 \pm 0.35^{\mathrm{a}}$ \\
\hline Wide part & ----- & $1.53 \pm 0.15^{\mathrm{a}}$ & ----- & $1.77 \pm 0.25^{a}$ \\
\hline Narrow part & ----- & $0.57 \pm 0.11^{a}$ & ----- & $0.20_{ \pm} 0.10^{\mathrm{b}}$ \\
\hline Posterior Fontanelle & $1.40 \pm 0.10^{\mathrm{a}}$ & $0.30 \pm 0.10^{b}$ & ----- & ----- \\
\hline Sphenoidal Fontanelle & ----- & ----- & ----- & $0.50 \pm 0.10$ \\
\hline Supra-occipital process & $2.27 \pm 0.25^{a}$ & $1.67 \pm 0.15^{b}$ & ----- & ----- \\
\hline Os interhyale & $0.40 \pm 0.1^{a}$ & $0.40 \pm 0.01^{\mathrm{a}}$ & $0.40 \pm 0.10^{a}$ & $0.30 \pm 0.10^{a}$ \\
\hline Os ceratohayle anterior & $1.87 \pm 0.15^{\mathrm{a}}$ & $1.87 \pm 0.15^{\mathrm{a}}$ & $1.87 \pm 0.15^{a}$ & $0.90 \pm 0.10^{b}$ \\
\hline Os ceratohayle posterior & $0.80 \pm 0.20^{a}$ & $0.90 \pm 0.10^{\mathrm{a}}$ & $0.83 \pm 0.15^{a}$ & $0.40 \pm 0.10^{b}$ \\
\hline Os hypohale dorsale & $0.23 \pm 0.06^{b}$ & $0.23 \pm 0.06^{b}$ & $0.45 \pm 0.07^{\mathrm{a}}$ & $0.23 \pm 0.06^{b}$ \\
\hline Os hypohale ventrale & $0.40 \pm 0.10^{b}$ & $0.40 \pm 0.10^{b}$ & $0.80 \pm 0.10^{a}$ & $0.43 \pm 0.06^{b}$ \\
\hline Hyoid bar & $3.80 \pm 0.71^{a}$ & $3.80 \pm 0.71^{a}$ & $4.50 \pm 0.71^{a}$ & $2.40 \pm 0.42^{b}$ \\
\hline Mandible & $4.60 \pm 0.14^{a}$ & $3.25 \pm 0.35^{b}$ & $3.17 \pm 0.15^{b}$ & $1.90 \pm 0.15^{\mathrm{c}}$ \\
\hline Mandibular tooth plate & $2.60 \pm 0.14^{b}$ & $1.60 \pm 0.14^{\mathrm{c}}$ & $3.10 \pm 0.10^{a}$ & $0.85 \pm 0.07 \mathrm{~d}$ \\
\hline Os orpeculare & $1.80 \pm 0.57^{b}$ & $3.70 \pm 0.42 \mathrm{a}$ & $1.75 \pm 0.35^{\mathrm{b}}$ & $1.80 \pm 0.56^{b}$ \\
\hline Hyomandibular canal & $0.25 \pm 0.07^{b}$ & $0.65 \pm 0.21^{a}$ & $0.85 \pm 0.07^{a}$ & $0.60 \pm 0.14^{a}$ \\
\hline \multicolumn{5}{|c|}{ Fenesta of trigeminofascial complex: } \\
\hline Proximal foramen & $0.35 \pm 0.07^{a}$ & $0.35 \pm 0.07^{a}$ & $0.45 \pm 0.07^{a}$ & $0.25 \pm 0.07^{b}$ \\
\hline Distal foramen & ----- & ----- & $0.25 \pm 0.07^{a}$ & $0.25 \pm 0.07^{\mathrm{a}}$ \\
\hline Grooves of lateroethmoideum & $1.60 \pm 0.14^{\mathrm{a}}$ & $1.10 \pm 0.14^{\mathrm{b}}$ & $1.60 \pm 0.14^{\mathrm{a}}$ & $1.10 \pm 0.14^{b}$ \\
\hline
\end{tabular}

Table 2. Different measurements of Oropharynx, some musculature and the pectoral spines of the Nile catfishes (Mean \pm SD). Values with different letters $(\mathrm{a}, \mathrm{b} \& \mathrm{c})$ within the same row differed significantly at least at $\mathrm{P}<0.05$.

\begin{tabular}{|c|c|c|c|c|}
\hline Measurements $(\mathrm{cm})$ & B. Bajad & C.gariepinus & M. electricus & S. Schall \\
\hline Length of oral gap limit & $2.7 \pm 0.17^{a}$ & $2.13 \pm 0.15^{b}$ & $2.96 \pm 0.15^{a}$ & $1.47 \pm 0.06^{\mathrm{c}}$ \\
\hline Width of oral gap limit & $4.03 \pm 0.16^{a}$ & $4.2 \pm 0.25^{\mathrm{a}}$ & $4.12 \pm 0.31^{a}$ & $2.0 \pm 0.20^{\mathrm{b}}$ \\
\hline Length of pharyngeal gap limit & $3.3 \pm 0.26^{\mathrm{a}}$ & $1.10_{ \pm 0.15^{\mathrm{c}}}$ & $1.93 \pm 0.21^{\mathrm{b}}$ & $1.50 \pm 0.20^{\mathrm{c}}$ \\
\hline Width of pharyngeal gap limit & $4.03 \pm 0.15^{\mathrm{a}}$ & $2.23 \pm 0.25^{b}$ & $2.87 \pm 0.11^{\mathrm{b}}$ & $2.07 \pm 0.26^{b}$ \\
\hline Length of the oral valve & $2.70 \pm 0.20^{a}$ & $1.07 \pm 0.12^{\mathrm{c}}$ & $1.93 \pm 0.12^{b}$ & $1.20 \pm 0.20^{\mathrm{c}}$ \\
\hline Width of the oral valve & $2.26 \pm 0.25^{b}$ & $2.13 \pm 0.15^{\mathrm{b}}$ & $2.97 \pm 0.15^{a}$ & $1.10_{ \pm} 0.11^{\mathrm{c}}$ \\
\hline Length of gill slit & $4.23 \pm 0.66^{\mathrm{a}}$ & $5.27 \pm 0.31^{\text {a }}$ & $2.47 \pm 0.15^{\mathrm{b}}$ & $2.20 \pm 0.20^{b}$ \\
\hline Limit of expansion of opercular cavity & $4.80 \pm 0.26^{\mathrm{a}}$ & $1.73 \pm 0.25$ b & $2.13 \pm 0.15^{\mathrm{b}}$ & $1.53 \pm 0.15^{b}$ \\
\hline Length of pectoral spine & $3.57 \pm 0.40^{b}$ & $2.7 \pm 0.20^{\mathrm{c}}$ & $2.13 \pm 0.15^{\mathrm{c}}$ & $6.87 \pm 0.23^{a}$ \\
\hline Width of pectoral spine & $0.43 \pm 0.15^{b}$ & $0.40 \pm 0.10^{\mathrm{b}}$ & $0.17 \pm 0.06^{\mathrm{c}}$ & $0.53 \pm 0.05^{a}$ \\
\hline Length of adductor mandibulae muscle. & $1.77 \pm 0.21^{b}$ & $0.83 \pm 0.06^{\mathrm{c}}$ & $3.70 \pm 0.17^{\text {a }}$ & $0.67 \pm 0.15^{\mathrm{c}}$ \\
\hline Width of adductor mandibulae muscle. & $4.13 \pm 0.15^{a}$ & $2.30 \pm 0.26^{b}$ & $3.67 \pm 0.29^{a}$ & $2.00 \pm 0.20^{b}$ \\
\hline Thickness of adductor mandibulae muscle. & $0.43 \pm 0.06^{b}$ & $0.37 \pm 0.05^{b}$ & $1.20 \pm 0.20^{\mathrm{a}}$ & $0.40 \pm 0.10^{\mathrm{b}}$ \\
\hline Thickness of adductor arcus palatini muscle. & $0.30 \pm 0.10^{\mathrm{b}}$ & $0.23 \pm 0.05^{\mathrm{b}}$ & $0.77 \pm 0.15^{\mathrm{a}}$ & $0.23 \pm 0.06^{b}$ \\
\hline
\end{tabular}

tendons and ligaments (SPRINGER and JOHNSON, 2000). The process of dissection and examination of specimens was carried out in the laboratory of fish disease and management in the faculty of Veterinary Medicine Benha University. Computed tomography was performed at 130 Kvolt and $14 \mathrm{~mA}$ by using Hitachi-CXR 4Multi-Slice CT scanner. Continuous transverse series of CT scan were obtained every $0.5 \mathrm{~cm}$ thickness. The research complied with protocols approved by the appropriate institutional animal care committee and adhered to the legal requirements of our country. Nomenclature used in this study was written according to Adriaens and Verraes (1998), Diogo (2007) and Schaller (2011). 


\section{Results}

\subsection{Comparative osteology of the head region in the Nile catfish}

This section describes in detail the comparative Osteology of Bayad or the silver catfish Bagrus bajad; African Catfish Clarias gariepinus; Raad or the electric catfish Malapterurus electricus and Schall Synodontis schall. It also included the bones forming the jaws and hyoid (bony feeding apparatus) (Figure 1). The following description arranges the bones of these fish skulls in twelve series. The bony parts stained red while the cartilaginous parts appeared blue in color (Figure 2.1, 2.2, 2.3). In M.electricus the skull is consists of both bones and cartilages as the frontal, parietal, supraoccipital, postparietal, sphenotic and pterootic are remain cartilages in mature fish, i.e. the posterior part of the roof of the cranium are cartilaginous (Figure 2.3).

Temporo-orbital series are the bones of the anteroventral of the orbital ring in addition to the posttemporosupracliethral bone. In the four studied species, Os lacrimale and Os infraorbitale II formed theanterior border of orbital ring. The ventral margin of orbital ring formed of Os infraorbitale II anteriorly and III posteriorly.

Os lacrimale (Figure 2.1) in the four species the lacrimal bone is triangular and connected by serrated suture with the lateral border of Os lateroethmoideum. The other bones of orbital series are in the form of curved rods (Figure 2.1), except the fourth infraorbital bone of C.gariepinus, which gives a large plate like dorsal process between Frontal and Posttemporo-supracleithral bones to form the dorsal margin of the orbital ring (Figure 2.2). The orbital margin in M.electricus is a complete ring of bone carried and attached anteriorly by the lacrimal bone and caudally by the stalk like suprapreopercular bone, these ring and its holders separated from the roof of the skull by a hollow oval cavity lodged the adductor mandibulae muscle.

Facial series is consists of three paired bones, Os premaxillare, Os maxillare and Os nasale. Os premaxillare are paired bones unite to each other by median symphysis, short ligaments to maxilla connect these bones laterally. In B.bajad and M.electricus the premaxilla carries rasp like tooth plate of villiform tooth nearly equal in size and length. In S.schall, the tooth plate is brush like formed of rows of long and thick cardiform teeth. In C. gariepinus the tooth plate carries villiform and conical teeth. Premaxilla in S.schall is relatively stout than that of the others, Table 1 .

Os maxillare are paired, rod like bones. Their proximal ends receive the base of maxillary barbles, while their distal end connected medially by short and strong ligaments to premaxilla and palatine bones. In B. bajad, Os maxillare is double the size of that of other studied species, Table 1. It also extends in the distal seventh of the maxillary barbles (Figure 2.1). Os nasale, these are paired bones, bound theexternal openings of nasal cavity. Os nasale sutured with os mesethmoideum and os lateroethmoideum medially, and short ligaments attached it to maxilla laterally.

Ethmoidal series, the ethmoidal series are represented by two single bones which are located at the median plane of the anterior part of skull, Os mesethmoideum and Os lateroethmoideum.
Os mesethmoideum carries two well-developed prethmoid cornu except in S.schall it has no cornu. The mesethmoid together with lateral ethmoid enclose Os nasale. The posterior edge of mesethmoid overlaps the anterior edge of frontal bones to form squamous suture. Os lateroethmoideum (Figure 2.1, 2.2, 2.3, 2.4) is an irregular bone and has two grooves directed toward frontal bone; these grooves are straight and shallow in S.schall and C.gariepinus while, in B. bajad and M.electricusare curved and deep Table 1 .

Vault series is that bones forming skull roof, in C.gariepinus, B. bajad and S. schall they are Os frontale and Os parietosupraoccipitale. In M.electricus they are Os frontale, and parietale, supraoccipitale and postparital cartilages. Os frontale are the largestpaired bones in skull Table $\mathbf{1}$, which separated by open median area, the anterior fontanelle. In B. bajad and M.electricus it is a deep slit fontanelle (Figures 2.1, 2.3), while in C.gariepinus and S.schall (Figures 2.2, 2.4) it is formed of two parts long slit anterior part, and narrow round posterior part Table 1. In M.electricus (Figure 2.3) the frontal bone is slender bone adjusted to surround anterior fontanelle leaving wide space between it and orbital series. In the other three species, the frontal bones are flat and irregular plate like. Frontal bones sutured rostrally with mesethmoid and lateral ethmoid bones, laterally with orbital series. They are also sutured posteriorly with parieto-supraoccipitale in C.gariepinus, B. bajad and $S$. schall with parietal bones in M.electricus and S.schall. These sutures are of serrated type. Os parieto-supraoccipitale, in C.gariepinus and B. bajad a median triangular supraoccipital process ended the parietosupraoccipitale bone posteriorly while in B. bajad this process is spine like (Figure 2.1) In M.electricus the parietal and supraoccipital cartilages are separated by clear serrated suture and small postparietal cartilage which present between them and the pterootic cartilage. In M.electricus (Figure 2.3) the parietal cartilage carries dorsally a thick bony median crest, which bifurcates caudally on the supraoccipital cartilage. The posterior fontanelle bounded by parietosupraoccipital bone in C.gariepinus and B. bajad and absent in M.electricus and S.schall. In C.gariepinus it is a narrow slit like, while in $B$. bajad it is in the same shape and depth of anterior fontanelle but shorter than it Table $\mathbf{1}$.

In S.schalla nuchal shield (Figure 2.4) is present caudal to the vault series, formed of a small round anterior nuchal plate, large and quadrate middle nuchal plate and two small triangular posterior nuchal plates.

Palatal series is formed of two single bones Os prevomerale and Os parashenoideum and three paired bones Os autopalatinum, Os metapterygoideum and Os entopterygoideum. Os prevomerale is an arrow shaped bone connected dorsally to the lateral ethmoid while ventrally the posterior edge of prevomeral forming a $\mathrm{V}$ shaped part which fit into a fissure or recess in parasphenoid to form foliate suture. In B. bajadand C.gariepinusit carriesa well-developed tooth plate while in S.schalland M.electricus the vomerine tooth plate is absent. Os parasphenoideum is the largest bone of palatine series forming the hard palate and anterior part of floor of neurocranium. It has two lateral wings that connected dorsally to pterosphenoid bones, orbitosphenoid anteriorly and prootics posteriorly. The body of parasphenoid is sutured posteriorly with basioccipitalis. Os 
autopalatinum are rod shaped bones. Its cranial end has two small articular cavities for the base of maxillary bone; medially the autopalatine articulates with a cylindrical facet of lateral ethmoid. Os metapterygoideum are fan shaped bones, sutured by serrated suture with quadrate bonesposteriorly.Os entopterygoideum are nearly triangular; which are sutured posteriorly with metapterygoid, dorsally with autopalatine and laterally with lateral ethmoid.

Sphenoid series is formed by two paired bones Os orbitosphenoideum andOs pterosphenoideum and the unpaired Os basisphenoideum. Os orbitosphenoideum together with pterosphenoid filled the gap between frontal and parasphenoid bones. The orbitosphenoid is located posterior to the wing of parashenoid and anterior to pterosphenoid, between it and the previous bone the optic foramen is present.

Os pterosphenoideum, at junction between the pterosphenoid and prootic are the fenestra of trigeminofascial nerve complex, in S.schall they are two wide foramina nearly equal in size, while in M.electricus there is a wide dorsal foramen and a narrow foramen just ventral to it. In C.gariepinus and B. bajad there is one foramen for trigeminofascial nerve Table 1. Os basisphenoideum, serrated suture is connected basisphenoid posteriorly with basioccipital and anteriorly with parasphenoid. Its dorsal border connected anteriorly to prootic and posteriorly to exooccipital.

Occipital series is formed of two unpaired bones Os supraoccipitale and Os exooccipitale and one paired bone, Os basioccipitale. Os exooccipitale, (Figure 2.2) the exooccipital forms the posterolateral wall of brain case, while the prootic forms its anteriolateral wall. It encloses the sagitta and asteriscus the otoliths of sacculus and lagena respectively. It perforated by foramina for glossopharyngeus, vagus and hypoglossal nerve. In order to locate sagitta (the largest otolith) in fresh catfish samples for estimating age, we suggest a simple and easy method, First, we used a scissor to make a longitudinal incision in the head which begins from the dorsal border of operculum and ended as far as possible toward anterior end of head. The prootic removed carefully by introducing a forceps in the fenestra of trigeminofascial trunk which is located in its anterior border, this easily done due to presence of serrated suture between it and exoocipital and the sagitta clearly appeared lodged in medial side of exooccipital. Os basioccipitale forms the most posterior part of floor of neurocranium. It is located ventral to weberian apparatus; its dorsal face has a cavity adapted to sinus impar perilymphaticus of weberian complex.

Otic series are the paired bones that formed otic series, Os sphenoticum, Os pteroticum, Os prooticum and Os epioticum. Os sphenoticum enclosed the anterolateral part of otic capsule. They are connected ventrally to prootic and pterosphenoid, and each one has an articular facet for hyomandibular bone.In M.electricus, they are cartilages (Figure 2.3). Os pteroticum, the pterotics are large bones form posterolateral part of otic capsule. In M.electricus, they are cartilages and sutured medially with parietal and supraoccipital cartilages, while in C.gariepinus and $B$. bajad they sutured with parietosupraoccipital (Figures 2.1, 2.2). The posterolateral part of pteroticum connected to posttemporo-supracleithral bone. It is connected ventrally to prootics and exooccipitalis. In $S$. schall it is extended laterally caudal to sphenotics and sutured ventrally to posttemporosupracliethrum bones leaving small and round open area, the lateral fontanelle (Figure 2.4). Os prooticum form anterolateral wall of brain case and enclosed utriculus and its otolith the lapillus. Os epioticum is a very small bone, located caudal to pterotic.

Medial series of mandible, the medial mandibular series suspends the mandible to the roof of skull (suspensorium), it is formed of two arms the upper one is the hyomandibula and the lower is the base of suspensorium, the quadrate bone. Os hyomandibulare, (Figure 2.1) which articulates with the cavity located on dorsomedial angle of opercular bone. The medial hyomandibular foramen is located 0.6$0.7 \mathrm{~cm}$ medio-dorsal to opercular process. In B. bajad the lateral hyomandibular foramen is located $0.5-0.6 \mathrm{~cm}$ lateral to opercular process, while in C.gariepinus it is located just ventral to the medial one and the canal between them is very short. In M.electricus, the hyomandibular canal located on medial surface of hyomandibula; its direction is nearly horizontal. In S.schall, the canal directed obliquely cranio-ventrally to open at lateral hyomandibur foramen on lateral surface of hyomandibula Table 1. Os quadratum is fan shaped in B. bajad and M.electricus andtriangular in C.gariepinus and $S$. schall. It is connected anteriorly by serrated suture with metapterygoid and posteriorly with the hyomandibula.

Lateral series of mandible, this series is formed of Os coronomeckelian, Os dentale and Os angulo-articulare. Os coronomeckelian, the mandible (Figure 2.2) formed by the union of coronomeckelian, anguloarticulare and dentale. The coronomeckelian lodged in the medial surface of mandible. Os dentale, the two dentaries are united at mandibular symphysis.It has two processes; the dorsal is the coronoid process and the ventral one articulates with the angular bone. In C.gariepinus the mandibular tooth plate carries two types of tooth, (Figure 2.2, 2.4) short villiform tooth anteriorly and conical tooth posteriorly. In M.electricus and B. bajad the tooth plate is rasp like formed only of short villiform tooth, while in S.schall it is brush like due to presence of long cardiform tooth with thick pointed apices (Figure 2.4). Os angulo-articulare is rod shaped in C.gariepinus and S.schall and short flat triangular in M.electricus and B. bajad (Figure 2.1, 2.3). It has retroarticular process for ligamentous attachment with interopercular and ceratohyoid bones.

Hyoid series is formed of six bones arranged from lateral to medial as the following:Os interhyale; Os ceratohyale anterior; Os ceratohyale posterior; Os hypohyale dorsale; Os hypohyale ventrale and Os parurohyale. Os interhyale is a small rod shaped bone; it connected dorsally to the hyomandibula and to the posterior ceratohyale ventrally by short ligaments. Os ceratohyale anterior, in the four catfishes, the anterior ceratohyale is double the length of posterior ceratohyale. It is fused ventromedially to the dorsal and the ventral hypohale. The anterior ceratohyale together with the posterior ceratohyale connected to branchiostegal rays by connective tissue. Os ceratohyale posterior is a triangular bone. It is sutured to os ceratohyale anterior by serrated suture. Os hypohyale dorsal is a small triangular bone. In M.electricusits the dorsomedial angle is attached to dorsal process of parurohyal by connective tissue and there is a V shaped gap between the two hypohal and the distal end 
of anterior ceratohyal, the gap is filled by membrane in the living state. Os hypohyale ventral is a small triangular bone. It is connected posteriorly by connective tissue to anterior edge of parurohyal. Os parurohyale is located at the midline just behind the hyoid symphysis. In C.gariepinus the body of the parurohyal is flat and square. It is xiphoid like in $B$. bajad and S.schall, while in M.electricus it is crown shaped. In C.gariepinus the body has three rod shaped processes, the ventral median and two lateral processes. In B. bajad and shall it has rod shaped ventral median process and two lateral triangular processes. In M.electricus a triradiate dorsal process is connected to the body of parurohyal.

Opercular series is formed of three bones, Os preoperculare, Os operculare and Os interoperculare. Os preoperculare (Figure 2.1) has two parts, the upper one articulates with the hyomandibular bone and the lower part articulates with the quadrate bone. Os operculare, in C.gariepinus the opercular bone is located horizontal to the flat head while in the other fishes it is located vertically in the head caudolateral side. Its dorsomedial angle formed an articular cavity for articulation with opercular process of hyomandibula to form a well-developed ball and socket joint. Os interoperculare is a small triangular bone; and attached by connective tissue to the lateral surface of posterior ceratohyal.

\subsection{Feeding mechanisms of the Nile catfish}

The jaws of the Nile catfishes are not protrudable and the feeding depends mainly on suction pressure. Suction feeding is divided into four stages, preparation, expansion, compression, and recovery.

Preparation phase starts when the buccal cavity increases as the catfish approaches its prey. The oro- buccal pressure increases by the adduction of the suspesorium and operculum and the lifting of the mouth floor. The muscles included in these phase are the adductor arcus palatini, Adductor Operculi and adductor mandibulae A2 (Figure 2.1, 2.3, 2.4). The adductor arcus palatini is inserted on entoppterygoid, metapterygoid, quadrate and hyomandibula (bones forming and attaching to suspensorium) and originate from the lateral part of the neurocranium floor. Adductor Operculi originates from the lateral surface of hyomandibula and inserts on dorsal process of opercular bone.These two muscles when act causes the inward movement of the suspensorium and operculum. In M. electricus (Figure 2.3) the adductor arcus palatini is more developed, stronger and thicker than in orther fishes Table 2. The adductor mandibulae A2 which inserts on medial surface of dentary bone may has a role in rising of mouth floor in this stage.

Expansion phase, in this phase the mouth is opened to full gape via mandibular and hyoid depression, abduction of the suspensorium and the opercular bone. The main muscles act for Lowering of the hyoid apparatus and the mandibles are the sternohyoideus and the hypoaxial muscles. The sternohyoideus is a large triangular muscle originates from the posterior portion of the parurohyal and inserted on anterior part of cleithrum. Levator arcus palatini is responsible for the abduction of the suspensorium as it originates from the lateral ethmoid and the frontal bones and inserted on the quadrate and the hyomandibula. In C.gariepinus, it also takes origin from the fourth infraorbital bone. Dilator operculi (Figure 2.3) and the levator opercula are the main dilator of the opercular cavity via abduction of the opercular bone. The two muscles insert on the medial surface of the operculum, the levator originates from the perotic in B. bajad and S. schalland from the pterotic and the suprapreopercular bones in C.gariepinus and M. electricus. The dilator opercula are originates from the posterior part of the frontal and the anterior part of the sphenotic.

In $B$. bajadthe branchiostegeal membrane is free from isthmus, the gill slit is wide and the oral valve is widely extended Table 2. The parieto- supraoccipital bone bounded with a long posterior fontanelle comparing to that of C.gariepinus, Table $\mathbf{l}$ the edges of the fontanelle may adduct and lift the floor of the neurocranium. The oral and the pharyngeal limits larger than those of the others, Table 2. All the previously mentioned structures maintain a maximum expansion not allowed in the other three studied species. In C.gariepinusthe oral gape limit is larger in width than in length which makes the mouth expends longitudinally than it does vertically.

In $S$. schall the branchiostegeal membrane is attached to isthmus, the gill slit is narrow and the oral valve is very narrow Table 2. S. schall has no posterior fontanelle and the oral and pharyngeal limits are smaller than those of the others, so the expansion phase is relatively limited.

Compression phase is the phase of mouth closure via the large adductor mandibulae and the adductor arcus palatines muscles. In $M$. electricus (Figure 2.3) these muscles are considerably strong and voluminous Table 2 , the frontal bones are slender bones adjusted to surround anterior fontanelle leaving wide oval space between them and the orbital series, that space lodged the two muscles of the compression phase. In the four species the adductor mandibulae is large muscle divided into four parts $\mathrm{Al}, \mathrm{A} 2$, A3 'and A3 '. The muscle as a whole taken its origin from preoperculare, metapterygoid and the suspensorium and inserts on the mandible.

Recovery phase involves a return of bones, muscles, and the oropharyngeal pressure to their pre- preparatory positions.

\section{Discussion}

Veterinary anatomy is mostly concerned with mammalian skull, while studying the Teleost skull is not common. The bones of the domestic animals easily classified into two main regions the cranium and the face (GETTY, 1975; NICKEL, SHUMMER and SEIFERLE, 1979), while the fish skull was an elaborate puzzle of articulating, highly variable bones. Bones important in the skull of one group may be totally absent from another, and equivalent bones were difficult to define among major taxonomic groups (MOYLE and CECH, 1996).

De Carli (1978), Kent (1992) and Kardong (2006) divided fish skull into two sets the neurocranium and the splanchnocranium. The neurocranium was the set of bones forming the brain case. In embryo, the splanchnocranium was formed of the derivatives of branchial arches. Adriaens and Verraes (1998) were considered dentary, splenial and angular bones parts of the splanchnocranium unless they're not derived from branchial arches. Kardong (2006) regrouped the bones of neurocranium and splanchnocranium into bony series. To prevent overlapping between bones 
of neurocranium and that of splanchnocranium, this work arranged the skull bones in twelve series, in other words we were arranged bones in clear parallel rows to ease the studying process. These series were the temporo-orbital, fascial, ethmoidal, vault, palatal, sphenoid, occipital, otic, hyoid, opercular and medial and lateral mandibular series.

This work aimed to demonstrate the utility of 3D computed tomography in fish. CT is superior to X-ray, crosssectional and prevents superimposition (SKERRITT and MCLELLAND, 1984). The normal appearance of the skull bones and fontanelles in computed tomography is important for clinical purposes, especially when dealing with congenital abnormalities which could be easily defined using CT. The thickness and the size of bones in relation to each other also clear, which may ease the diagnosis of nutritional diseases, as in the case of calcium deficiency and hormonal disturbances.

Types of Sutures did not take suitable considerations in most literatures, Known sutures are of four classes, sutura serrata was formed at which edges of bones have irregular interlocked margins, where these edges were beveled or overlapped each other sutura quamosa was formed. Sutura plana, was formed between the smooth edges of bones, Sutura foliata a rare type in mammalian skull of suture was formed when a $\mathrm{V}$ shaped edge of one bone was fited into a recess in the adjacent one where extreme stability was desirable (GETTY, 1975), most of sutures in the studied catfish skulls were of the serrated type. The posterior edge of mesethmoid was overlapped the anterior edge of frontal bones to form squamous suture. The prevomeral bone has a V shaped edge which fitted into a recess of the parasphenoid to form a clear foliate suture which described by Adriaens and Verraes (1998) in C.gariepinus and Diogo (2007) in pimelodidae or antenna catfish as a $\mathrm{V}$ shaped suture.

Catfishes obtained this name after their barbles; B.bajad has a large barbles reach the caudal border of operculum. These barbles were moved by the maxillary bones in Bagridae and were larger compared with the other catfishes (BURGESS, 1989). The measurements of maxillary bones were double sized those of the three species, Table 1. It was enclosed the base of maxillary barbles (ADRIAENS and VERRAES, 1998) in C.gariepinus and (DIOGO, 2007) in pimelodidae, but in B.bajad the maxillary barbles was enclosed the base and extended to distal seventh of the maxillary barbles.

Teeth very important for food prehension in catfishes; our studies revealed that, premaxillary and dentary tooth plates were carried villiform teeth in B.bajad and M.electricus, these rows of teeth were nearly equal in height and the plates were rasp like. While in $S$. schall the premaxillary teeth were villiform but with pointed round ends and the dentary tooth plate was in the form of long curved filaments or cardiform teeth, overlapping each other when the mouth close. A villiform vomerine tooth plate was present in B.bajad, C.gariepinus, and absent in both M.electricus and S. schall, these results agree with (BURGESS, 1989) in Bagridae and Malapteruridae. In C.gariepinus the premaxillary tooth plate was formed of villiform teeth, the vomerine plate formed of conical teeth while the dentary plate was formed of both types of teeth, these agree with (ADRIAENS and VERRAES, 1998) in C.gariepinus and disagree with (BURGESS, 1989) who mentioned that the tooth plates of C.gariepinus were carried villiform teeth only.
Concerning feeding habits of the Nile catfishes M. electricus and B. bajad are piscivores (SAGUA, 1979; BAKHOUM and FATAS, 2003). C. gariepinus was omnivores, while $S$. schall feeding mainly on mollusks (BURGESS, 1989).

Results showed that, in $S$. schall the mouth is sub-terminal or ventral in position, while in the other three species it was terminal. In $S$. schall the upper lip was in the form of hard pad to scratch Algae or small mollusks from hard rocks, then taken by the brush like cardiform teeth of the mandible. $S$. schall is one of the upside-down fishes, it feeds on the undersurfaces of water plants leaves, do so while swimming upside down, that's one of the benefits of its ventral mouth (HELFMAN, COLLETTE, FACEY et al., 2009).

Jaws of the Nile catfishes are not protrudable, as the maxillary bone an important element in jaw protrusion (LAUDER, 1985) is modified to bear the base of the maxillary barbles and not share in jaw formation. They depend mainly on suction feeding, which divided by Lauder (1985) into four phases, preparation, expansion, compression and recovery.

Our results revealed that, the expansion phase was extreme in piscivores fishes, M. electricus and B. bajad, as the oral and pharyngeal limits opened in suitable dimensions to accommodate their prey size, Table 2, the expansion phase in $S$. schall was limited comparing to other studied species, due to narrow dimensions of jaw, hyoid apparatus Table 1, oropharyngeal gap limits, gill slit and the attached branchiostegeal membrane. All the previously mentioned structures may aid in increasing bucchal pressure during preparation phase and may help in sucking small invertebrates which may hide in crakes or stuck to hard rocks.

The fontanelle (Fonticuli cranii), well known in newly born head in man as described by Hollinshead and Rosse (1985) and Gray (2000) and in dog as mentioned by Adams (1996), whose defined fontanelle as an open area covered by a tough membrane. There were two large fontanelles the anterior (frontal) and the posterior fontanelle (parietal), and two small fontanelles the sphenoidal (fonticulus sphenoidalis) and mastoid (Fonticulus mastoideus).

Our results revealed that, the anterior fontanelle was present in the four studied species; while the posterior one was absent in M.electricusand S.schall. Adriaens and Verraes (1998) reported that, the posterior fontanelle also known as the parietal foramen, exposed pineal gland to direct sun light. In S.schall a third paired and small fontanelle was present, the lateral fontanelle. It is located between sphenotic, pterotic and posttemporo-supracliethrum bones, in this position it resembled the sphenoidal fontanelles of mammales, which located between the sphenoid, parietal, temporal and frontal bones (HOLLINSHEAD and ROSSE, 1985) in man and (SCHALLER, 2011) in dog. The question raised here is why catfishes has such fontanelles, Artenerr, Pekney and Gergelova (2003) reported that, in man the fontanelles provide two important functions, First, they provide space between the bones and make the newly born skull flexible during the childbirth. Second, they support the fast growth by their expansions. We suggest that, the fontanelles make the roof of the skull flexible especially during expansion phase of suction feeding, as their edges may adduct then raising the floor of the neurocranium to increase the width of the oropharyngeal cavity. The absence of the posterior fontanelle in M.electricus which also substituted by the 
presence of the flexible cartilaginous roof may support our suggestions. This roof may be squeezed by the aid of the attached muscles, and raise the floor of the neurocranium. The oropharyngeal limits of the M.electricus are slightly small compared with their size Table 2 , and to their prey size (piscivores), so widen their mouth by raising the floor of the neurocranium is feasible.

\section{References}

ADAMS, DR. Canine anatomy, a systemic study. 5th ed. Ames: Iowa State University Press, 1996. p. 191-211.

ADRIAENS, D. and VERRAES, W. Ontogeny of the osteocranium in the African catfish, clarias gariepinus (Burchell, 1822) (Siluriformes: Clariidae): ossification sequence as a response to functional demands. Journal of Morphology, 1998, vol. 235, n. 3, p. 183-237. http://dx.doi.org/10.1002/(SICI)10974687(199803)235:3<183::AID-JMOR2>3.0.CO;2-8

ARTENERr, J., GERGELOVA, K. and PEKNEY, P. Atlas of human skeletal anatomy. Ulm: University of Ulm, 2003. p. 23-24. Available from: <http://www.jurajartner.com/>.

BAKHOUM, SA. and FATAS, SN. Food and feeding habits of Bayad fish Bagrus bajad (forsskal, 1775) in El-Nozha hydrodrome, Alexandria, Egypt. Egyptian Journal of Aquatic Biology and Fisheries, 2003 , vol. 7 , n. 3, p. 197-211.

BURGESS, WE. An atlas of fresh water and marine catfishes: a preliminary survey of the siluriformes. New Jersey: TFH Publications, 1989. p. 36-182.

DE CARLI, F. The world of fish. New York: Abbeville Press Publishers, 1978. p. 30-32.

DIOGO, R. Osteology and Myology of the cephalic region and pectoral girdle of Heptapterus mustelinus, comparison with other heptapterins, and discussion on the synapomorphies and phylogenetic relationships of Heptapterinae and the Pimelodidae (Teleostei: Siluriformes). International Journal of Morphology, 2007, vol. 25, n. 4, p. 735-748. http://dx.doi.org/10.4067/ S0717-95022007000400011

EBBELL, B. The Ebers papyrus. Kopenhagen: Levin \& Munkagaard, 1937.

GETTY, R. General osteology and general arthrology. In SISSON, S., GROSSMAN, JD. and GETTY, R. Sisson and Grossman: the anatomy of the domestic animals. 5th ed. Philadelphia: W.B. Sounders Company, 1975. p. 19-33; 43-38.

GRAY, H. Gray's anatomy of the human body features. 20th ed. theBartleby.com ed. Philadelphia: Lea \& Febiger, 1918; New York: Bartleby.com, 2000.
HELFMAN, GS., COLLETTE, BB., FACEY, DE. and BROWEN, BW. The diversity of fishes: biology, evolution, and ecology. 2nd ed. Oxford: Wiley-Blackwell, 2009. p. 23-124.

HOLLINSHEAD, H. and ROSSE, C. Text book of anatomy. 4th ed. Philadelphia: Harper \& Row, 1985. p. 853-877.

HRAPOWET, IH. Grundriss der medizin der Alten Agypter IV. Berlin: Akademie-Verlag, 1960.

KARDONG, KV. Vertebrates, comparative anatomy, function, evolution. 4th ed. New York: Mc-Graw Hill, 2006. p. 406-445.

KENT, G. C. Comparative anatomy of the vertebrates. 9th ed. Mexico: Mc-Graw Hill, 1992. p. 293-313.

LAUDER, GV. Functional morphology of the feeding mechanism in lower vertebrates. In (ed. DUNCKER, HR. and FLEISCHER, G. Vertebrate morphology. New York: Gustav Fisher Verlag, 1985.

LUE, AJ., FANG, WD. and MANOLIDIS, S. Use of plain radiography and computed tomography to identify fish bone foreign bodies. Otolaryngology-Head and Neck Surgery, 2000, vol. 123, 4, p. $435-438$.

MOYLE, PB. and CECH, J. An introduction to ichthyology. 3rd ed. Mc-Graw Hill, 1996. p. 21-28.

NICKEL, R., SHUMMER, A. and SEIFERLE, E. The locomotor system of the domestic animals. 2nd ed.. Berlin: Verlag Paul Parey, 1979. p. 125-161.

SAGUA, V. Observations on the food and feeding habits of the African electric catfish Malapterurus electricus (Gmelin, 1789). Journal of Fish Biology, 1979, vol. 15, p. 61-69. http://dx.doi. org/10.1111/j.1095-8649.1979.tb03572.x

SCHALLER, O. Illustrated veterinary anatomical nomenclature. Thieme Medical Publishers, 2011. 624 p.

SKERRITT, GC. and MCLELLAND, J. An introduction to the functional anatomy of the limbs of the domestic animals. Bristol: Wright, 1984. p. 191-193.

SPRINGER, VG. and JOHNSON, GD. Use and advantages of ethanol solution of Alizarin Red $S$ dye for staining bone in fishes. Copeia, 2000, vol. 1, p. 300-301.

TAYLOR, WR. and VAN DYKE, GC. Revised procedures for staining and clearing small fishes and other vertebrates for bone and cartilage study. Cybium, 1985, vol. 9, n. 2, p.107-119.

Received August 28, 2013 Accepted September 11, 2014 


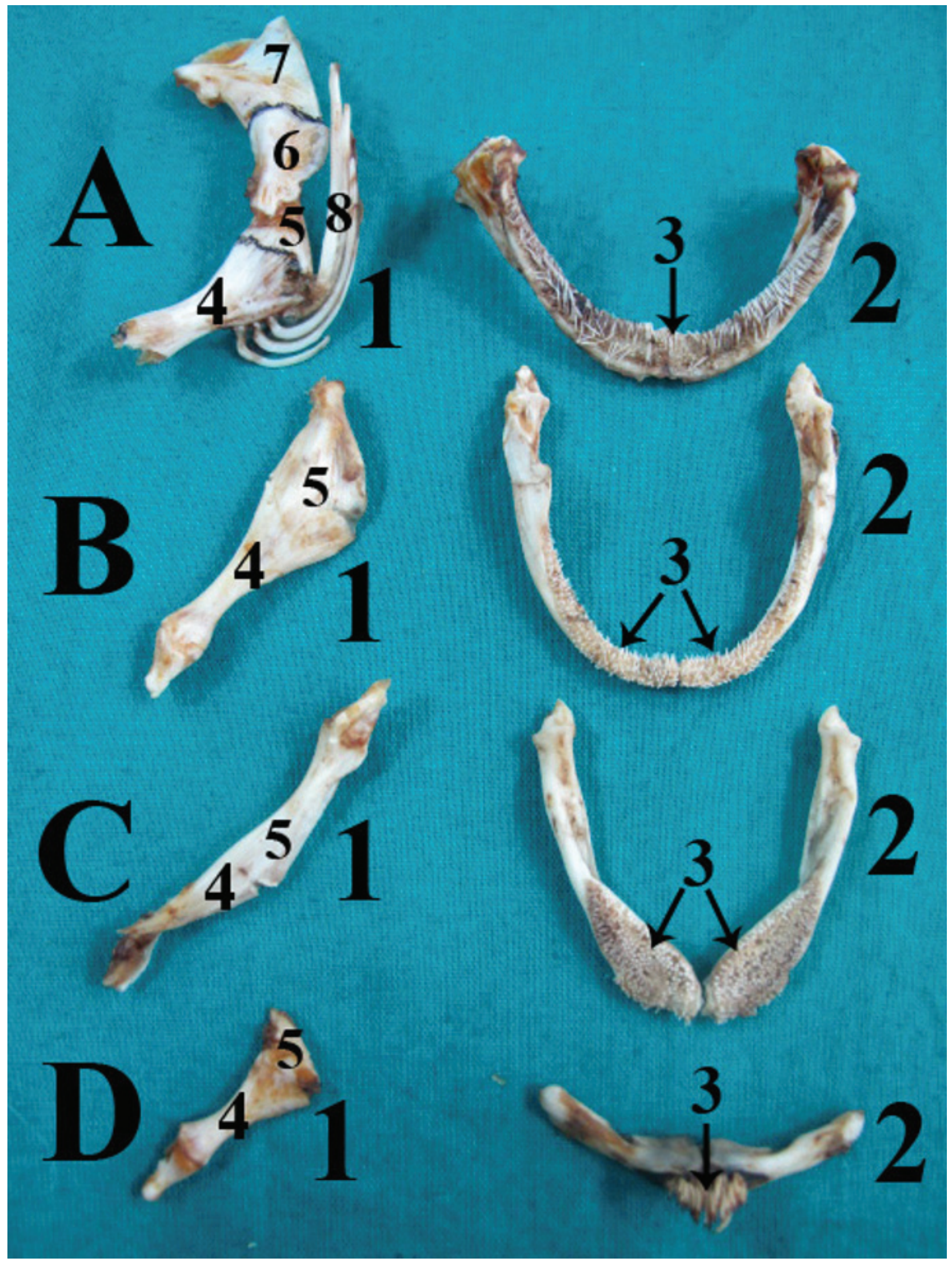

Figure 1. A photograph of the main bony anatomical structures included in the feeding process in M. electricus (A), B. bajad (B), C. gariepinus (C), S. schall (D) showing: 1-Hyoid bar; 2- Mandible;3-Dentary tooth plate; 4-Os Ceratohyale anterior; 5-Ceratohyale posterior; 6- Os interopercular; 7- Os Opercular; 8- Branchostegial rays. 

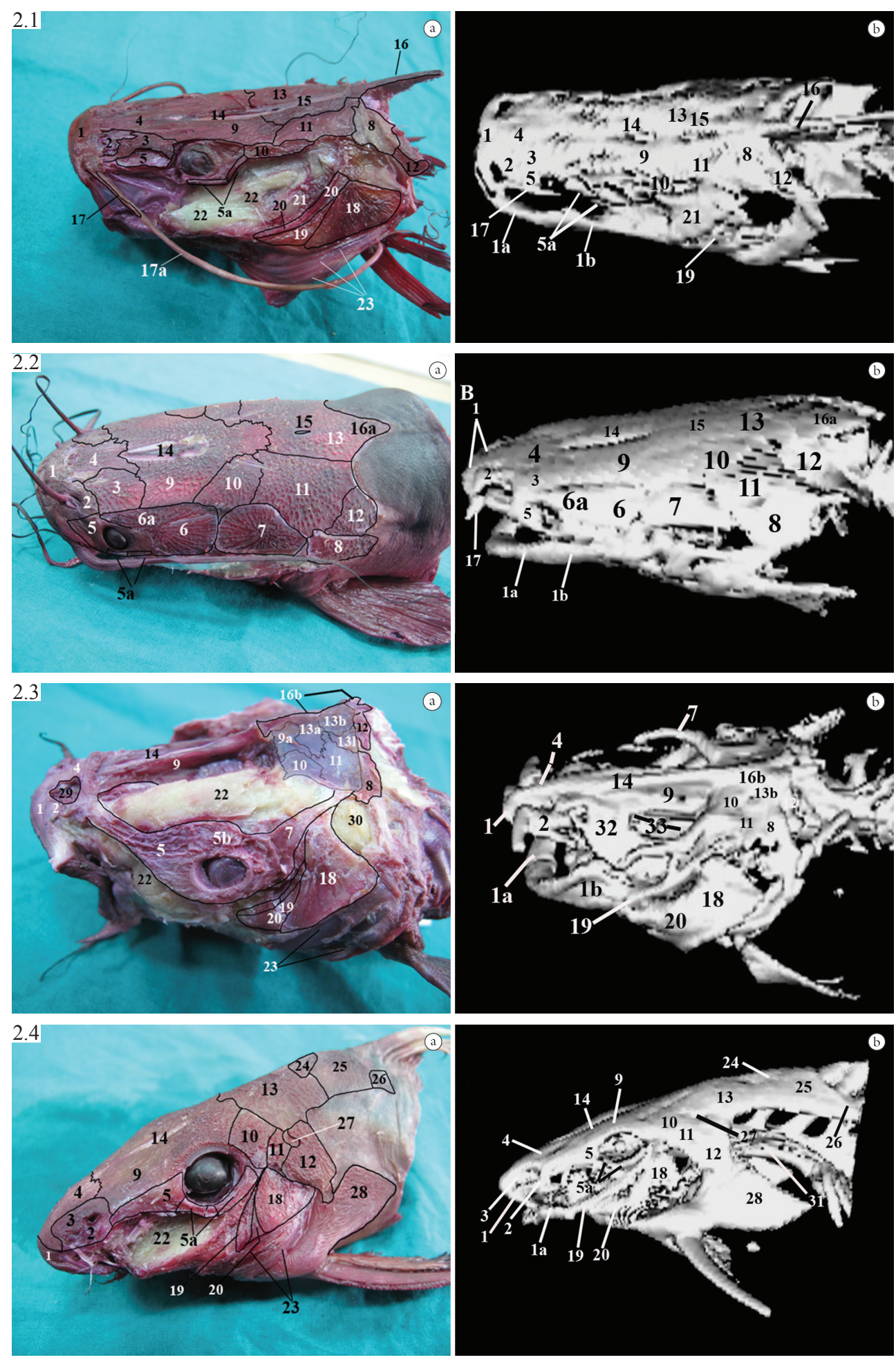

Figure 2. A photograph of dorso-lateral view of double stained skull of B. bajad, C. gariepinus, M. electricus and S. schall respectively, with their 3D C.T image in Fig (2.1b), Fig (2.2b), Fig (2.3b), Fig (2.4b) showing: 1- Prethmoid cornu except in schall, 1- Hard pad covers premaxilla. la- Os dentale. 1b- Os quadratum. 2- Os nasale. 3- Os latero-thmoideum. 4- Os lacrimale. 5a- Infraorbital bones. 5b- Orbital ring (in M. electricus). 6- Fourth infraorbital bone. 7- Suprapreopercular bone. 8- Posttemporo-supracliethrum bone. 9- Os frontale. 9a- Cartilaginous part of Os frontale. 10- Os sphenoticum (cartilage in M. electricus). 11- Os pteroticum (cartilage in M. electricus). 12- Os Exooccipital. 13- Os parieto-supraoccipitale. 13a- Parietal cartilage. 13b- Supraoccipital cartilage. 131- Postparietal cartilage. 14- Anterior cranial fontanelle. 15- Posterior cranial fontanelle. 16- Supraoccipital spine. 16a- Supraoccipital process. 16b- Supraoccipital crest. 17- Os maxillare. 17a- maxillary barble. 18- Os operculare. 19- Os preoperculare. 20- Os interoperculare. 21- Os Hyomandibulare. 22- Adductor mandibulae. 23- Branchiostegal rays. 24- Anterior nuchal plate. 25- Middle nuchal plate. 26- Posterior nuchal plate. 27- Lateral fontanelle. 28- Cliethrum. 29- Nasal fossa. 30- levator operculi muscle. 31- Weberian apparatus. 32- Os metapterygoideum. 33- Cavity lodged by adductor mandibulae. 